[DOI: 10.24214/jecet.A.10.4.65261]

Jaurnal of Environmental Science, Computer Science and Engineering \& Technology

An International Peer Review E-3 Journal of Sciences and Technology

Available online at www.jecet.org

Section A: Environmental Science

Research Article

\title{
Perception of Climate Change, Environmental Impacts and Endogenous Adaptation Strategies implemented by Misenge Farmers in the Hinterland of the city of Kindu, Province of Maniema in the Democratic Republic of Congo
}

\author{
Gloire Mukaku Kazadi*, Pierre Yuma Madjaliwa, Défi Amuri Assani , \\ Lingot BULEDI AMURI
}

Université de Kindu. Faculté de Sciences Agronomiques. Département de, Gestion des Ressources Naturelles (GRN), Zootechnie et de Phytotechnie. BP 122 Kindu (RDC).

Received: 18 July 2021; Revised: 22 August 2021; Accepted: 26 October 2021

\begin{abstract}
This study was carried out in the town of Kindu from December 2020 to February 2021 and had the overall objective of determining the perception of climate change, the environmental impacts and the endogenous adaptation strategies implemented by the farmers of Misenge to deal with this phenomenon. To achieve this, the data collection techniques used were mainly based on sociological surveys carried out with 123 farmers in Misenge and the percentage chosen as a comparison index of the significance level of the data. It therefore emerged that the agriculture practiced in Misenge is mainly rain-fed ( $100 \%$ of farmers); no farmer in Misenge has access to agricultural credit or is subsidized, only $14 \%$ of farmers in Misenge admitted to having received training on different agricultural technologies at least once. The decrease and irregularity of the rains, the late start of the rainy season, the early stopping of the rains, the higher frequency of dry sequences, the occurrence of violent winds and eddies, dust mists; hotter days, increasingly hotter nights, shortened cold periods, appearance and extension of barren soils, gravelly soils, appearance and spread of crop diseases and pests, decrease in herbaceous plants, drying out and death of trees are all facts observed
\end{abstract}


by the inhabitants of Misenge which may be attributable to climate change. So to face these climate changes, the farmers of Misenge implement and use several strategies: Appeal to the gods (54\%), Cultural nomadism (89\%), use of seeds of improved varieties (12\%), adjustment of the agricultural calendar. compared to sowing periods $(85 \%)$, the use of chemical fertilizers to increase yields (2\%).

Keywords: Climate change, adaptation, endogenous strategies.

\section{INTRODUCTION}

In Africa, climate change is accompanied by unprecedented effects. For example, there are declining agricultural yields, short growing seasons and changes in rainfall patterns, making access to water difficult. Africa's population is expected to reach two billion in less than 37 years and, in 86 years, three in four births will occur on the continent. Declining agricultural yields and population growth will put additional pressure on an already fragile food production system. In such a context, experts point out that, if the current situation continues, Africa will only be able to meet $13 \%$ of its food needs by 2050 . This will also pose a new threat to some $65 \%$ of the population.

African workers whose livelihood depends on agriculture, including children and the elderly - the first victims of food insecurity. Today, some 240 million Africans are already hungry. By 2050, an increase of around 1.2 to 1.9 degrees Celsius will suffice to increase the number of undernourished Africans by between 25 and 95\% ( $+25 \%$ in Central Africa, $+50 \%$ in East Africa, $+85 \%$ in Southern Africa and + $95 \%$ in West Africa). The situation will be catastrophic for children, whose success in school depends on proper nutrition. ${ }^{[1]}$.

In addition to the fact that the conditions of agricultural production are made more and more difficult by the vagaries of the weather ${ }^{[2,3]}$. They also generate significant environmental changes, such as droughts whose recurrence accelerates forest decline ${ }^{[4-7]}$, reduced plant cover and agricultural yields, and promotes the extension of denuded areas ${ }^{[8]}$.

To the Intergovernmental Group of Experts on Climate Change (GIEC, 2007) to go further by estimating that the consequences of climate change on the economies of African countries are already considerable, and the situation could be even more dire given the predictions increase in the frequency of extreme events with global warming ${ }^{[9]}$. These impacts are particularly important in developing countries where agriculture is $100 \%$ rain-fed without any alternative to irrigation and constitutes the main source of employment and income for the majority of the population ${ }^{[10-12]}$.

Faced with all these hazards, farmers are trying to adapt in their own way by implementing several strategies. And this need for populations to adapt to climate change and their socio-environmental impacts is essential because their survival depends on it ${ }^{[13]}$. According to Clark ${ }^{[14]}$ the most effective and sustainable adaptation measures are often those taken at the local level, directly involving the people concerned.

The adaptation practices developed by producers in response to the negative consequences of climate change depend on their perception and endogenous knowledge of these changes ${ }^{[15]}$. Farm households in the town of Kindu and its hinterlands are not at all spared from the devastating effects of climate change. Thus, analyzing the perceptions, the environmental impacts as well as the endogenous adaptation strategies put in place by the farmers of the hinterland of the town of Kindu, in the case of the village of Misenge, is the main object of this study. 


\section{METHODOLOGY USED}

\subsection{Environment:}

(a).Geographical setting: Let us note first of all that due to the lack of specific climatic and physical data specific to the village of Misenge and based on its proximity to the town of Kindu, we will attribute the latter's characteristics to it.The village of MISENGE, is located in the Democratic Republic of Congo, Province of Maniema, in the Territory of Kailo, around the town of Kindu, Kilometric Point 14, Lokandu axis; the latter administratively depends on the territory of Kailo, collectivity of Bangengele., Groupement de Senge and district of Kindu.

The geographic coordinates of this medium are as follows:

- $\quad-2 \circ 52$ 'South latitude

- $25^{\circ} 52$ 'east longitude

- 486 m altitude

(b).Climate: The type of climate dominating this zone is tropical humid Subequatorial corresponding to <AW4> according to the Koppen classification where we have two seasons:

- Dry season with 4 months, which begins in mid-May until mid-August; due to climate change, this season begins rather and widens a little more;

- Rainy season with 8 months, which begins from mid-August until mid-May if we do not take into account the disturbances mentioned above.

(c).Vegetation: Being near the city of Kindu, which is occupied in the North by the dense humid forest, in the South by the shrub savannah. Within it, there are a few grassy savannas to the south-west of the city, while in its south-east, on the edge of the province of South Kivu, there is a mosaic of vegetation [16].

(d).Hydrography: The Congo River crosses the province from South to North, it is navigable from Kindu to Lubutu (Province Orientale). It is watered by several tributaries, the most important of which are: Lulindi, Musukuyi, Mulonge, Ulindi, Kasuku, Kunda, Lufubu, Lowe, Lueki and Elila. Note that the city of Kindu is crossed by the Congo River which separates the commune of Alunguli from those of Kasuku and Mikelenge. The tributaries of the Congo River which are found on both sides in this part are: Mikelenge River, Lwandoko, Kindu, Misenge, Kange, Lononga and Mesobo. In the right bank (municipality of Alunguli), we find the tributaries below the rivers Kabondo, Mangobo, Kamikuga, Mutchondo and Mesobo, while on the left bank we have the presence of tributaries like: Mikelenge, Makopo and Kapondjo ${ }^{[16]}$.

(e).Soil and relief: The relief is that which characterizes the end of the Congolese central basin, very little broken with the soil which varies between the clay-sandy and sandy-clay types. This region has an agricultural soil (sandy clay) which allows the practice of all kinds of crops, both cash and food.

\subsection{Material:}

as part of this research, the most important materials used are therefore: a survey questionnaire, a Casio Fx-350MS brand scientific calculator for various calculations, a notebook to keep the data collected, a Samsung brand phone incorporating a GPS application, for collecting geographic coordinates; and a $\mathrm{PC}$ for the automatic processing of our data. 


\subsection{Methods:}

In general, all scientific research uses rigorous, well-defined, transferable operating procedures that can be applied under the same conditions and adapted to the genre. We have used different methods in this study; these are the following methods:

(a).Observation method: It allowed us to take cognizance of the data which cannot reach us by empirical observations, thus to live the reality on the ground.

(b).Documentary method: for the realization of this study, we also used various works (virtual and non-virtual).

(c).Comparative method: this allowed us to compare our results with those obtained by other researchers.

(d).Descriptive statistical method: It allowed us not only to analyze the data but also to convert it into an encrypted form, and at the same time also facilitating the interpretation of the field results.

(e).Inductive method: Going from the particular to the general, this consisted of estimating the general characteristics of a population from the characteristic of a known sample.

2.3.1. Techniques used: Techniques are stages, operations limited to concrete practical elements, adopted for a defined purpose. They are only tools made available to research.

(a).Direct interview: Here, the (prepared) questions are put directly to the respondents in order to record their answers.

(b).Questionnaire: The questionnaire technique is the same as the interview, except that in these cases here, the answers are transcribed directly next to the questions previously asked on a survey form.

2.3.2. Sample determination: The sample is a representativeness that includes a number of individuals, objects, or observation development allowing conclusions to be drawn applicable to the entire population to which the choice was made. To do this, our sample was made up of 123 farmers from Misenge.

2.3.3. Criteria for choosing respondents: Be the head of the household, living in Misenge, exercising agriculture as a main activity for more than 10 years and this one must be of an age greater than or equal to 45 years. This age criterion is explained by the fact that the evolution of the climate is very slow and it is adults who may have some experience. It is also assumed that by age 10, an individual is able to memorize and reveal certain significant facts about climate change and changes in the natural environment.

2.3.4. Data processing: For the data processing, we have chosen the percentage as a comparison index of the significance level of the data. The data analysis consisted of recording the frequencies relating to the various questions and presenting them in the form of tables, after having converted them into a percentage, according to the following formula:

$$
F r=\frac{F o}{N} x 100
$$

\section{Where}

Fo: observed frequency; Fr: Relative frequency; N: Total Number of Observations. 


\section{RESULTS.}

3.1. Socio-economic characteristics of agricultural households in misenge: It emerges from this figure on the socio-economic characteristics of the farmers of Misenge that $73 \%$ of them are men and $27 \%$ are women, $60 \%$ of the people we surveyed are illiterate, all the farmers of this region practices rain-fed agriculture, $42 \%$ of them in addition to agriculture practice breeding as a secondary activity, $11 \%$ engage in petty trade; Only $14 \%$ of the farmers in Misenge told us that they were trained in different agricultural technologies, and $100 \%$ of the people we interviewed do not belong to any peasant organization, do not receive subsidies or agricultural credits.

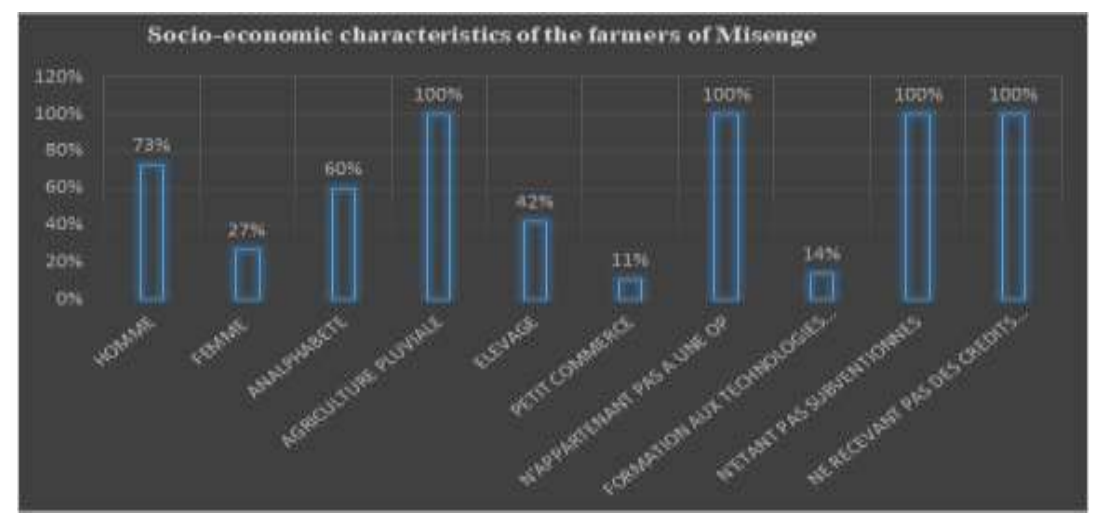

\subsection{Changes observed by the agricultural households of misenge:}

\subsubsection{Climate Parameters}

(a).Rainfall regime: Regarding the rainfall regime, $87 \%$ of the farmers we met perceived it to be changing in terms of the decrease in the amount of rains and periods of drought a little longer compared to past periods, $92 \%$ estimated that the rains became more and more intense when they arrived, $79 \%$ criticized the late start of the rains, $79 \%$ of the farmers we met mentioned in particular the early stops of the rains compared to the agricultural season and at the end $95 \%$ of them perceived as change in recent years, the irregularity of the rains.

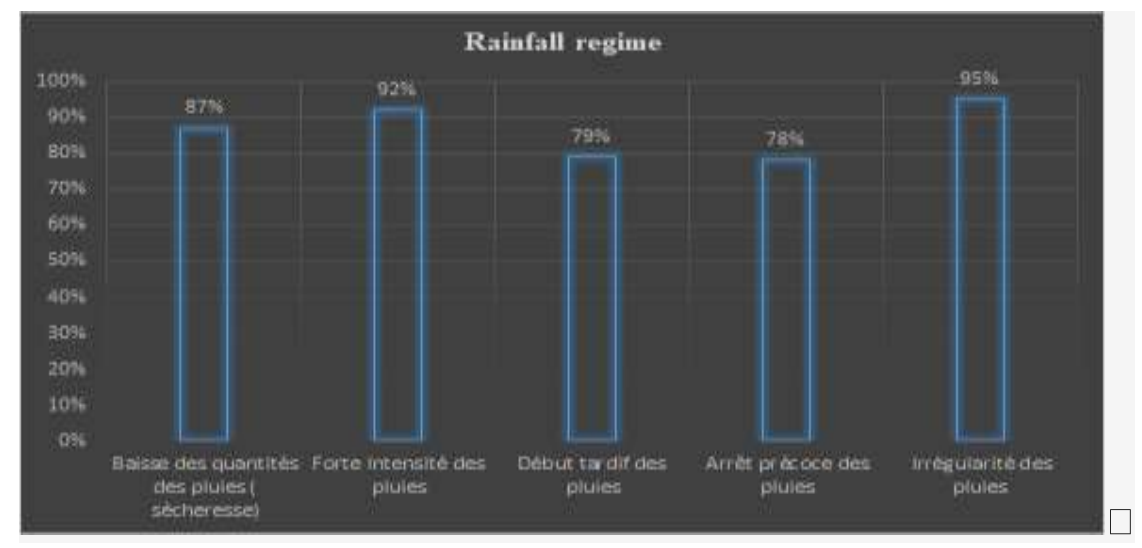

(b).Wind parameter: Regarding the wind parameter, $92 \%$ of the people we surveyed made particular reference to the strong winds that are increasingly felt, $79 \%$ of them told us to have noticed such violent eddies and $82 \%$ have refers to the mists of dust which have become more and more noticeable with the approach of the dry season and can persist for many days. 


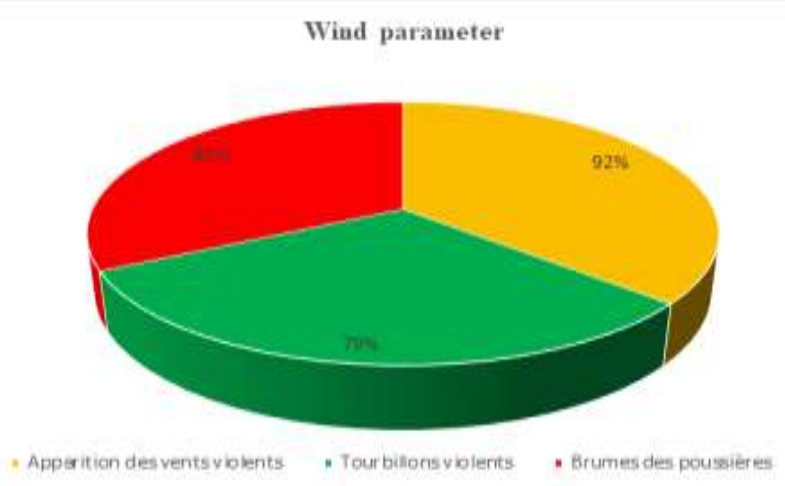

(c).Temperature: Misenge farmers recognize that the days (87\%) and nights (79\%) are getting hotter and colder periods are getting shorter. These results reflect, in a way, an increase in daily maximum and minimum temperatures observed throughout the year. They perceive this warming of temperatures through its impacts on their activities.

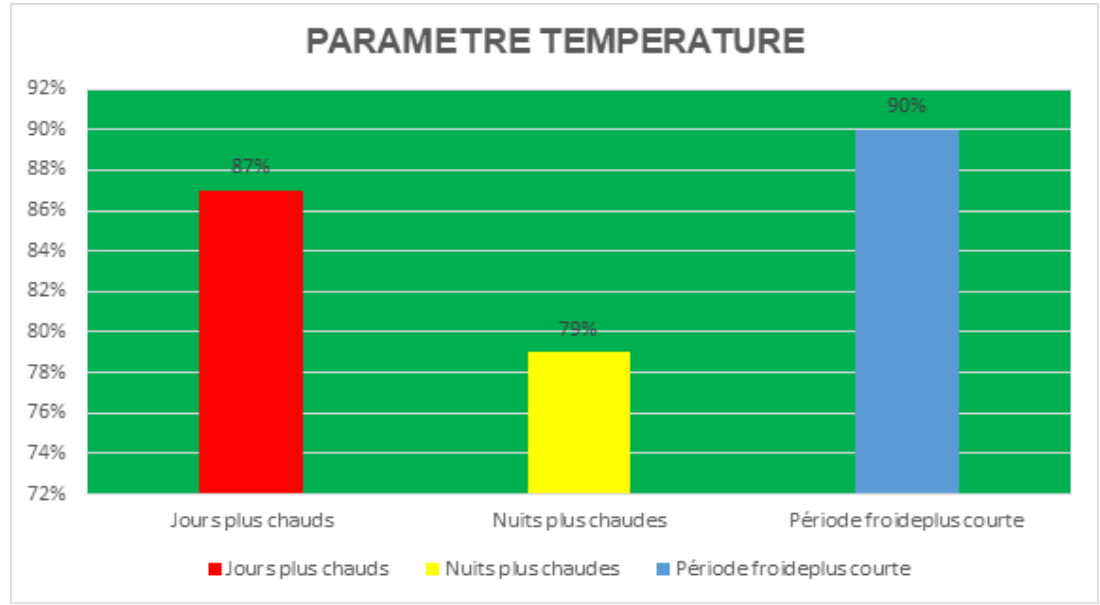

3.2.2.Recorded Environmental Changes: The following environmental modifications were perceived by the farmers of Misenge: extension of bare soils (85\%), the appearance and extension of gravelly soils (32\%), appearance and extension of erosion gullies $72 \%$, appearance and extension of crop diseases (90\%), reduction of herbaceous plants (68\%) and ultimately drying out and death of trees (74\%).

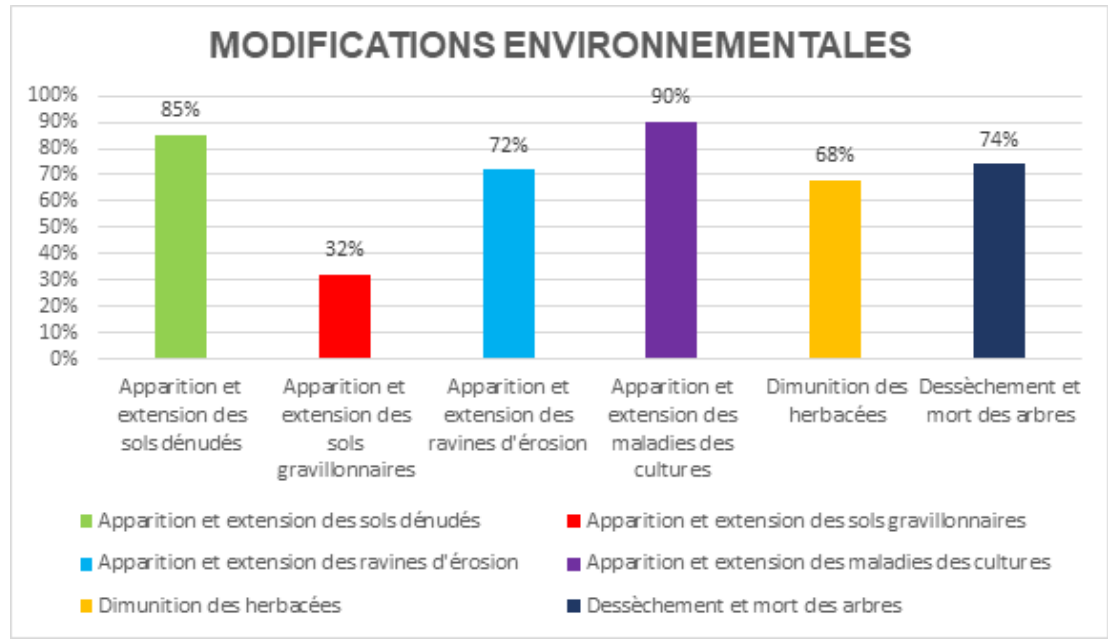


3.3. Agronomic Parameters: The decline in agricultural yield was observed by all the farmers we met and according to them the following causes are at the base of this situation: decrease in soil fertility, noted by $42 \%$ of the total surveyed, $29 \%$ have attributed this situation to the late start of the rains, $14 \%$ believe that this is mainly because of the early end of the rains, for $9 \%$ of the people we surveyed, it is the resurgence of diseases and plant parasites which is at the origin of the drop in agricultural yields and in the end $6 \%$ thought that it was rather the action of strong winds.

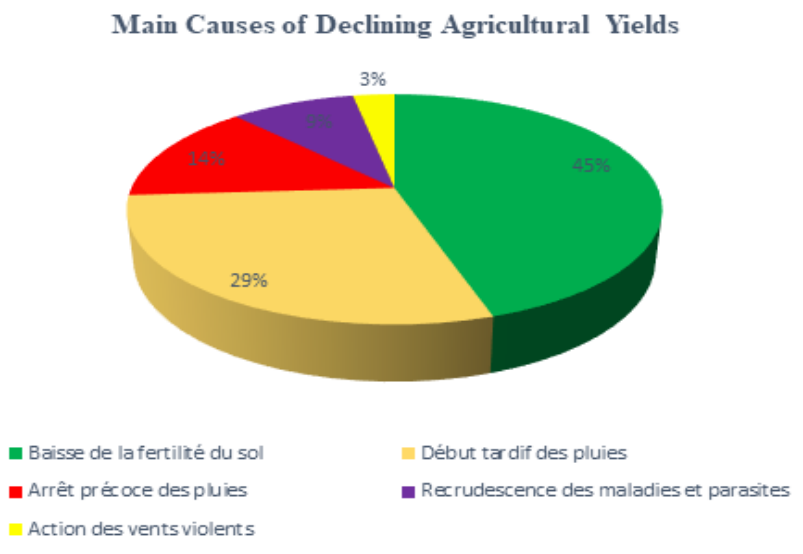

3.4. Adaptation strategies implemented by Farmers in Misenge: To cope with climate change, the farmers of Misenge have developed several strategies: cultural nomadism (89\%), adjustment of crop sowing periods ( $85 \%), 54 \%$ of them appeal to the gods, $12 \%$ told us to face this situation by using seeds of improved and resistant varieties; and only $2 \%$ told us they use engrains.

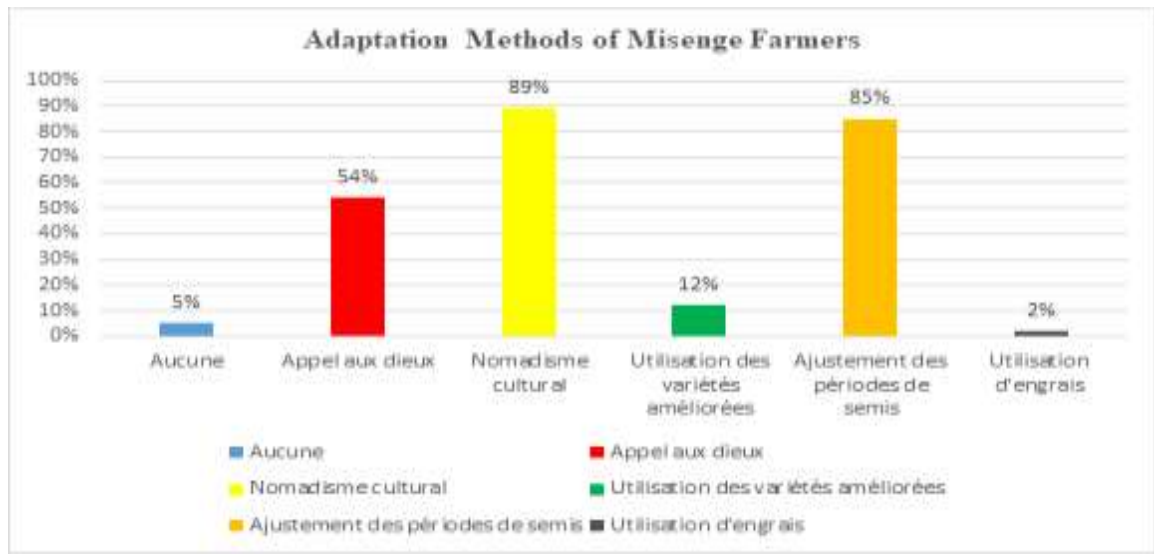

\section{DISCUSSION}

4.1.Socio-economic characteristics: In particular, it emerged during our studies that rain-fed agriculture is $100 \%$ practiced by agricultural households in the village of Misenge, thus confirming several studies that have been carried out on the characterization of agriculture practiced in Africa like Beucher. and Bazin et al. ${ }^{[17]}$ for whom African agriculture is mainly rainfed; its low level of irrigation makes it even more particularly vulnerable to the vagaries of the climate, which is extremely variable and changeable. To this dependence of agriculture on climate, we must add the fact that African farmers do not receive any subsidy [in terms of inputs in particular] do not have access to agricultural credits, only a very small proportion of the rural population (less than $10 \%$ in Africa) as such, it is difficult for them to be trained or to invest in agricultural technologies that would boost their activities, even the 
simplest [couplings, tillers, irrigation systems, etc.]. which is added to so many others which make African agriculture so vulnerable. ${ }^{[18]}$. Exactly similar situation to what we found on land where no farmer has access to agricultural credit or is subsidized, only $14 \%$ of farmers that we surveyed admitted to us having already benefited at least once from a training on different agricultural technologies.

4.2. Changes Observed: The farmers of Misenge perceive climate change through facts such as: The decrease and irregularity of the rains, the late start of the rainy season, the early cessation of the rains, the higher frequency of dry sequences, the occurrence of violent winds and eddies, increasingly remarkable dust mists especially during the dry periods which moreover do not cease to become elastic during the year. These facts have also been perceived by West African farmers as signs of climate change in their environment, as revealed in the work of ${ }^{[19-21}$. Warmer days, increasingly hot nights, shortened cold periods, appearance and extension of barren soils, gravelly soils, appearance and spread of crop diseases and pests, reduction of herbaceous plants, drying out and death of trees have also confirmed to us. as perceived by the farmers of Misenge as being the environmental modifications attributable to climate change, As moreover mentioned by the group of Intergovernmental Expert on the study of Climate (GIEC) in 2007.

4.3. Adaptation strategies: Speaking of adaptation, let's say first of all that adaptation is generally seen as the ability of a natural or human system to adjust to present or future changes, so as to benefit from them, to be able to withstand them. or limit its negative effects. So to face climate change the farmers of Misenge implement and use several strategies, these can be classified in the category of spontaneous adaptation measures because quite simply the farmers did not wait for the fallout from international negotiations. to adapt to variations in climate, and have already developed various strategies to adapt to the new conditions they already face.

These strategies can be summed up mainly in: Appeal to the gods (54\%), Cultural nomadism (89\%), use of seeds of improved varieties (12\%), adjustment of the agricultural calendar in relation to sowing periods (85\%), use of fertilizers to increase yields (2\%). Our results contrast a little bit with those of Kabore $e t a l .{ }^{[22]}$ in an almost similar study carried out in the north center of Burkina Faso, a study which revealed that the main adaptation strategies put in place by the peasants were: the abandonment of certain crops known as rents such as cotton and tobacco for the benefit of cereals such as sorghum and millet due to recurrent droughts, reduced rains and the scarcity of fertile land. Other techniques such as Zai on bare land have also been reported by the same source as part of the range of strategies implemented by Burkinabe farmers to cope with the negative impacts of climate change they face. This slight difference in the adaptation strategies taken by the farmers of Misenge in the Democratic Republic of Congo and those of Burkina Faso in particular and generally those of West Africa, can be justified in a way by the training. technologies and agricultural subsidies to which West African farmers have access, although still insufficient but still higher in proportion to those of Misenge in the Democratic Republic of Congo.

\section{CONCLUSION}

In conclusion, let's say that the purpose of this study was to analyze the perceptions of Misenge farmers in the face of climate change, its environmental impacts as well as the endogenous adaptation strategies they are implementing to deal with this phenomenon. Changes in rainfall are felt through signs such as decreased rainfall, early cessation of rains, shortening of the duration of the rainy season. Changes in temperature and wind are felt through indicators such as increasing temperature and the occurrence of increasingly violent winds. ; With negative impacts on the biophysical environment and negative repercussions on agricultural production. Thus, faced with all these hazards and the absence of concrete support measures, the populations try very little to adapt by implementing many strategies such as the 
call to the gods, cultural nomadism, the use of seeds of improved varieties, adjustment of the agricultural calendar in relation to the sowing periods, the use of fertilizers to increase yields.

\section{REFERENCES}

1. Richard Munang et Jesica Andrews, L'Afrique face au changement climatique, Afrique Renouveau, édition spéciale Agriculture 2014.

2. T.Caquet, Des systèmes innovents face au changement climatique, INRA Dept EFPA/MP ACCAF, Science \& Impact. APCA-ADEME, Paris France, 2014,16p.

3. A.Chanzy, G. Martin, N. Colbach, M. Gosme, M. Launay, C. Loyce, A. Métay, S.Novak Adaptation des Cultures et des Systèmes de culture au changement climatique et au Nouveaux usages Institut National de la Recherche Agronomique, Centre de Recherche Val de la Loi, Orléans, France www.ea.inra.fr, 10 juillet 2015, 5p.

4. Belem, B., F. Kagambega-Mueller, R. Bellefontaine, J.P. Sorg, U. Bloesch et E. Graf, 2017, Assisted Natural Regeneration with Fencing in the Central and Northern zones of Burkina Faso, Tropicultura, 35, 2, pp. 73-86

5. Ouédraogo, A. et A. Thiombiano, 2012, Regeneration pattern of four threatened tree species in Sudanian savannas of Burkina Faso, Agroforestry Systems, 86, pp. 35-48

6. Higgins, I.S., M.C. Shackleton et R.E. Robinson, 1999, Changes in woody community structure and composition under contrasting land use systems in semi-arid savanna, South Africa, J. Biogeogr, 26, pp. 619-627

7. Grouzis, M. et J. Albergel, 1989, Du risque climatique à la contrainte écologique. Incidence de la sécheresse sur les productions végétales et le milieu au Burkina Faso. In : Eldin M. et Milleville P.(Eds). Le risque en agriculture. Orstom, Coll. à Travers champs, Paris, France. 260 p.

8. D.Bambara, A. Bilgo, E. Hien, D. Masse, A. Thiombiano et V. Hien, Perceptions paysannes des changements climatiques et leurs conséquences socio à Tougou et Donsin, climats sahélien et sahélo soudanien du Burkina Faso. Bulletin de la Recherche Agronomique du Bénin (BRAB), Numéro 74. ISSN 1840 - 7099.2013,

9. J.T.Houghton, Y. Ding, D.J. Griggs, M. Noguer, P.J. Van der Linden, X. Dai, K. Kabore et Al, 2019

10. D.S.M.Agossou, C.R.Tossou, V.P.Vissoh, K.E.Agbossou, Perception des perturbations climatiques, savoirs locaux et Stratégies d'adaptation des producteurs agricoles béninois. African Crop Science Journal 2012, 20, 565-588. [En ligne, http://www.bioline.org.br/ request? cs12069.

11. Delille H., 2011, "Perceptions et stratégies d'adaptation paysannes face aux changements climatiques à Madagascar : Cas des régions Sud-ouest, Sud-est et des zones périurbaines des grandes agglomérations", http://www.avsf.org/public/posts/704, Consulté en septembre 2013, $108 \mathrm{p}$.

12. A.A.Enete and A.N.Onyekuru, Challenge of Agricultural Adaptation to Climate Change: Empirical Evidence from Southeast Nigeria. Tropicultura,2011, 29 (4), 243 - 249. 
13. OCDE, Climate Change and Agriculture: Impacts, Adaptation, Mitigation and Options for the OECD [COM/TAD/CA/ENV/EPOC (2009)13].

14. D.Clark, Climate Change and Social/Cultural Values in the Southwest Yukon: A Resilience Building Perspective, pour le Northern Climate Exchange, Waterloo, 2016, 41p.

15. R.Dimon, Adaptation aux changements climatiques : perceptions, savoirs locaux et stratégies d'adaptation des producteurs agricoles des communes de Kandi et de Banikoara au Nord du Bénin. Thèse d'ingénieur agronome, FSA-UAC,2008, 132 p.

16. Anonyme, Rapport annuel de la Mairie de Kindu 12èmepage,2010.

17. Beucher Et Bazin et al, L'agriculture en Afrique face aux défis du changement climatique, 2012 .

18. Audrey-Brule Françoise et al., le crédit à l'Agriculture, un outil clé du développement agricole, dans Techniques financières et Développement 2016/3-4 (n²124) P35 à 52.

19. B.S.Sarr, M. Atta, S. Ly, T. Salack, S. Ourback, Subsol et D.A. Geoges, Adapting to climate variability and change in smalholder farmin communities : A case study from Burkina Faso, Chad and Niger (CVADAPT), Journal of Agricultural Extension and Rural Development,2015, vol. 7, 1, pp. 16-27.

20. J.A.Nielsen et A. Reenberg, Temporality and the problem with singling out climate as a current driver of change in a small West African village, Journal of Arid Environments, 2010,74, pp. 464-474.

21. M. Ouédraogo, Y. Dembélé et L. Somé, Perceptions et stratégies d'adaptation aux changements des précipitations : cas des paysans du Burkina Faso. Science et changements planétaires / Sécheresse 21 (2) : 87 - 96. Doi : 10.1684/sec.2010.0244.

22. Kabore, Bruno Barbier, Paulin Ouoba, André Kiema, Léopold Some et Amadé Ouedraogo, Perceptions du changement climatique, impacts environnementaux et stratégies endogènes d'adaptation par les producteurs du Centre-nord du Burkina Faso,2019

\section{* Corresponding Author: Gloire Mukaku Kazadi}

Université de Kindu. Faculté de Sciences Agronomiques. Département de, Gestion des Ressources Naturelles (GRN), Zootechnie et de Phytotechnie. BP 122 Kindu (RDC).

Online date of publication: 28.10.2021 